\title{
Screening for liver disease in vinyl chloride workers
}

\author{
F. I. LEE ${ }^{1}$, D. S. HARRY ${ }^{2}$, W. G. F. ADAMS ${ }^{3}$, AND M. LITCHFIELD \\ From the Departments of Medicine (Gastroenterology) ${ }^{1}$ and Pathology ${ }^{2}$, Victoria Hospital, Blackpool, \\ ICI, Mond Division, Hillhouse Works ${ }^{3}$, and Central Toxicology Laboratory, ICI, Alderley Park ${ }^{4}$
}

\begin{abstract}
Following the occurrence of hepatic fibrosis and angiosarcoma in polyvinyl chloride autoclave workers, a screening programme was set up for workers at risk in a large production plant. There was no significant difference in liver function tests between workers and a control group of men in the same factory, not exposed to vinyl chloride. Four exposed workers out of 422 were found to have enlarged spleens compared with none out of 202 controls. Liver biopsies from selected cases showed no significant pathological changes, although there was minimal increase in portal tract and sinusoidal fibrosis in exposed workers.
\end{abstract}

Two reports from Germany (Marsteller et al., 1973; Lange et al., 1974) have described the syndrome of vinyl chloride disease in autoclave workers involved in the manufacture of polyvinyl chloride (PVC). The syndrome includes Raynaud's phenomenon, scleroderma-like skin changes, splenomegaly, thrombocytopenia, hepatic fibrosis and portal hypertension, acro-osteolysis and a restrictive defect in the lung function tests. Subsequently, reports of hepatic angiosarcoma in autoclave workers (Creech and Johnson, 1974; Block, 1974; Lee and Harry, 1974) raised the question of the prevalence of liver damage in men apparently at risk. A screening programme was accordingly set up to study this and related aspects. This report relates to findings in one plant (ICI, Hillhouse, near Blackpool) concerned in the production of vinyl chloride monomer (VCM) and PVC.

\section{The plant}

The factory has been engaged in the manufacture of VCM and its subsequent polymerisation to PVC since the early 1940s. Until 1969 VCM was manufactured by the acetylene route. Since then the ethylene route has been used, ethylene being converted to ethylene dichloride which is 'cracked' to vinyl chloride, $\mathrm{C}_{2} \mathrm{H}_{3} \mathrm{Cl}$ by heating. PVC is produced by transferring the monomer in liquid form to an autoclave, adding water and catalyst and carrying out the polymerisation reaction at a controlled

Received for publication 30 June 1976

Accepted for publication 25 August 1976 temperature. The polymer in slurry form is then dried to a powder.

During most of the 1960s the threshold limit value (TLV) for VCM was accepted as $500 \mathrm{ppm}$ time weighted average (TWA) exposure over eight hours. In 1972 a TLV of $200 \mathrm{ppm}$ was introduced in the UK. In 1974 VCM was recognised as a human carcinogen and special new hygiene limits were set which varied somewhat from country to country. In the UK the current hygiene limit is $10 \mathrm{ppm}$ TWA, averaged over an eight-hour period.

It is difficult to know with any degree of certainty what were the exposure levels prior to 1970 because relatively few measurements were either required or made, although Barnes (1976) attempted to assess past exposure levels. On the older VCM manufacturing plants, concentrations could have been up to 500 ppm at times, although TWA personal exposures would have been lower. The concentrations of VCM on polymerisation plants tended to be higher than on monomer producing plants and local high concentrations of VCM could be found, for example, when autoclaves were opened, and during autoclave cleaning. These local concentrations of VCM could have been well in excess of $500 \mathrm{ppm}$ but again TWA personal exposure was probably lower. From 1970 onwards, plant concentrations came down in anticipation of a $200 \mathrm{ppm}$ TLV and by 1973 personal exposures were $150 \mathrm{ppm}$ or less. The events of 1974 led to a dramatic drop in plant concentrations to less than $50 \mathrm{ppm}$ in 1974, and less than $10 \mathrm{ppm}$ in 1975 in conformity with the standard set in the British Code of Practice (Health and Safety Executive, 1975) agreed by government, unions and industry. 


\section{The study}

Initially, men considered to have the highest exposure were studied. These were workers on the autoclave floors of the polymerisation plants and the monomer plant processmen with more than five years service. In all, 422 volunteers from this group were examined, a response rate of approximately $93 \%$. A control group of 202 men was taken from workers in the same factory who had no contact with vinyl chloride. The age range was roughly comparable to that of the exposed group, but no direct matching was attempted.

A full clinical history and examination were carried out. Particular attention was paid to alcohol and drug usage, history of previous liver disease, evidence of Raynaud's phenomenon, the presence of hepatosplenomegaly and stigmata of chronic liver disease. Serum aspartic transaminase (SGOT) (Kessler et al., 1971), serum alanine transaminase (SGPT) (Kessler et al., 1971), alkaline phosphatase (Axelsson et al., 1965), gamma-glutamyl transferase $(\gamma \mathrm{GT})$ (Boehringer Kit No. 15944) and bilirubin levels (Boehringer Kit No. 15794) were estimated by autoanalyser. In addition a platelet count was carried out. The standard deviations from the mean of the results of the first 50 controls were calculated. Repeat blood specimens were examined when any of the biochemical estimations were above three standard deviations from the mean. In view of the emphasis on a low platelet count in previous studies, it was felt that tests giving results below two standard deviations from the mean should be repeated. Tests were repeated not less than four weeks after the first venepuncture. Men in whom both specimens showed deviations were assessed by a hospital consultant and investigated appropriately. Another full clinical assessment was carried out and evidence of liver disease sought. Men whose abnormalities could not readily be explained had further labora-

Table 1 Numbers involved at each stage of the investigation, including diagnosis in cases where inpatient investigation was not carried out

\begin{tabular}{lcc}
\hline Numbers of workers & Exposed & Control \\
\hline Initial examination & 422 & 202 \\
First test abnormal & 41 & 21 \\
Repeat test abnormal & 21 & 14 \\
Gilbert's syndrome & 4 & 2 \\
Chlopromazine & 1 & -1 \\
Paget's disease & - & 6 \\
Mild enzyme abnormalities & - & - \\
Retired & 1 & 5 \\
Investigated further in hospital & 15 & \\
\hline
\end{tabular}

tory tests, barium studies, upper gastrointestinal endoscopy, technetium colloid scanning of the liver and spleen, and liver biopsy (Trucut or Menghini needles). The number involved at each stage of this procedure is shown in Table 1 . As a result of the laboratory tests, 21 exposed workers $(5 \%)$ and 14 controls $(7 \%)$ were selected on the previously agreed criteria for further study. Details of the abnormalities are shown in Tables 2 and 3.

\section{Findings}

RESULTS: EXPOSED WORKERS (TABLE 4)

Four exposed workers had unconjugated hyperbilirubinaemia considered to be due to Gilbert's disease - a benign hereditary condition. One man was found to have been on a course of chlorpromazine at the time of the blood tests, and the result of repeat testing at a later date was normal. Another man with a single enzyme abnormality suffered from severe chronic bronchitis and withdrew without further tests. Fifteen men therefore progressed to the stage of hospital investigation.

Eleven men had worked on the autoclave plant and four on the monomer plant. From their histories none of the men took alcohol to the extent that serum enzyme abnormalities would be expected. One man had mild Raynaud's phenomenon which did not materially interfere with his activities. Suspected hypothyroidism in one man was confirmed on further investigation; clinical response to replacement therapy was satisfactory. No man was considered to have a large liver but the spleen was palpable in three.

Tests for Hepatitis Bs Antigen were negative and levels of $\alpha_{1}$ fetoprotein within the normal range. There were weakly positive tests for mitochondrial antibodies in three men, and antinuclear factor and smooth muscle antibodies each in one man.

Bromsulphthalein excretion was impaired in four of the men. Barium meal examination showed a deformed duodenal cap in two patients, and gastroscopy showed mild to moderate oesophagitis in three more. These findings were not considered significant. Neither technique gave any evidence of oesophagogastric varices.

Technetium scan of the liver showed patchy uptake in four patients. Splenomegaly was confirmed in three men in whom the spleen had been palpated and was shown in one more. The liver scan in one man showed a defect in the lower border but a subsequent cholecystogram confirmed that this was due to gall bladder indentation.

RESULTS: CONTROL WORKERS (TABLE 5) Fourteen men had abnormal tests on two occasions. 
Table 2 Abnormal screening tests in exposed workers

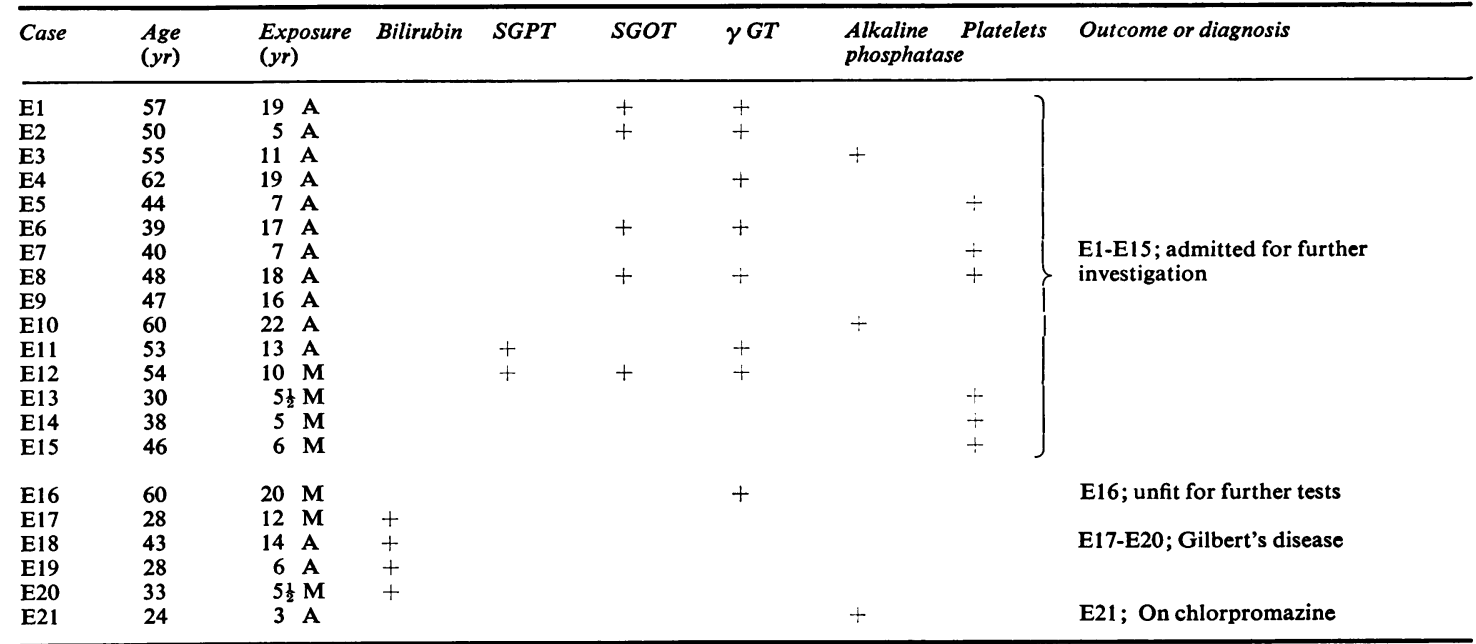

$\mathbf{A}=$ autoclave worker; $\mathbf{M}=$ monomer plant worker.

Table 3 Abnormal screening tests in control workers

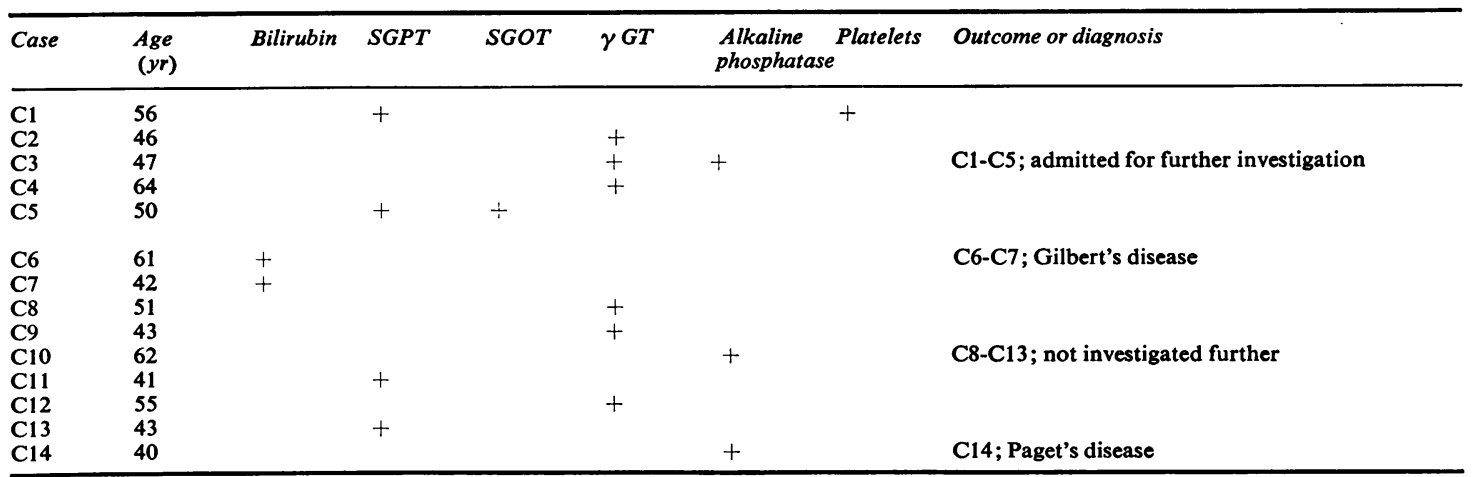

Two had presumed Gilbert's disease accounting for unconjugated hyperbilirubinaemia and one had Paget's disease of bone accounting for a raised alkaline phosphatase. Six had such marginal elevation of enzyme levels that further investigation was not considered justified. In two of these, regular heavy intake of alcohol could account for $\gamma \mathrm{GT}$ elevation. Five men therefore were admitted to hospital for further investigation.

All five were Hepatitis Bs Antigen negative and $\alpha_{1}$ fetoprotein levels were normal. Two men had weakly positive mitochondrial antibodies.

Bromsulpthalein excretion was impaired in four of the five men. The barium meal examination showed duodenal cap deformity in one man. Gastroscopy confirmed this and showed oesopha- gitis in another. There was no evidence of oesophagogastric varices. The technetium scan showed abnormal uptake suggestive of cirrhosis in two men.

\section{LIVER BIOPSIES IN EXPOSED WORKERS}

Needle biopsies were obtained from the 15 exposed men admitted to hospital. Changes were not marked, although there were interesting features in two cases. In one the liver contained sarcoid-like granulomata; further investigation including full blood count, erythrocyte sedimentation rate, chest radiograph, plasma proteins, tissue antibodies, serum calcium and Brucella agglutinins were negative. The cause of the granulomata is not known. Biopsy in another man showed intense fatty infiltration and prominent capsular fibrosis. Careful 
Table 4 Further tests in exposed workers

\begin{tabular}{|c|c|c|c|c|c|}
\hline Case & $\begin{array}{l}\text { BSP retention } \\
(\%)\end{array}$ & Scan & Barium meal & Endoscopy & Antibodies \\
\hline $\begin{array}{l}\text { E1 } \\
\text { E2 }\end{array}$ & $\begin{array}{l}2 \cdot 5 \\
7 \cdot 0\end{array}$ & $\begin{array}{l}\text { Patchy hepatic uptake } \\
\text { Patchy uptake } \\
\text { Spleen enlarged }\end{array}$ & $\begin{array}{l}\text { Normal } \\
\text { Normal }\end{array}$ & $\begin{array}{l}\text { Normal } \\
\text { Normal }\end{array}$ & ANF+ \\
\hline $\begin{array}{l}\text { E3 } \\
\text { E4 }\end{array}$ & $\begin{array}{r}7 \cdot 5 \\
13 \cdot 5\end{array}$ & $\begin{array}{l}\text { Normal } \\
\text { Patchy uptake }\end{array}$ & $\begin{array}{l}\text { Normal } \\
\text { Duodenal } \\
\text { diverticulum }\end{array}$ & $\begin{array}{l}\text { Normal } \\
\text { Pyloric ulcer }\end{array}$ & $\begin{array}{l}\text { MA+ } \\
\mathbf{M A}+\end{array}$ \\
\hline $\begin{array}{l}\text { E5 } \\
\text { E6 } \\
\text { E7 } \\
\text { E8 } \\
\text { E9 } \\
\text { E10 }\end{array}$ & $\begin{array}{r}22 \cdot 0 \\
8 \cdot 9 \\
3 \cdot 0 \\
20 \cdot 0 \\
6 \cdot 0 \\
3 \cdot 5\end{array}$ & $\begin{array}{l}\text { Spleen enlarged } \\
\text { Normal } \\
\text { Spleen enlarged } \\
\text { Spleen enlarged } \\
\text { Normal } \\
\text { Normal }\end{array}$ & $\begin{array}{l}\text { Normal } \\
\text { Normal } \\
\text { Normal } \\
\text { Normal } \\
\text { Normal } \\
\text { Duodenal } \\
\text { diverticulum }\end{array}$ & $\begin{array}{l}\text { Oesophagitis } \\
\text { Oesophagitis } \\
\text { Normal } \\
\text { Duodenal ulcer } \\
\text { Oesophagitis } \\
\text { Normal }\end{array}$ & $\begin{array}{l}\bar{z} \\
\overline{M A}+\end{array}$ \\
\hline $\begin{array}{l}\text { E11 } \\
\text { E12 } \\
\text { E13 } \\
\text { E14 } \\
\text { E15 }\end{array}$ & $\begin{array}{r}4 \cdot 5 \\
10 \cdot 0 \\
7 \cdot 0 \\
4 \cdot 5 \\
3 \cdot 5\end{array}$ & $\begin{array}{l}\text { Normal } \\
\text { Normal } \\
\text { Normal } \\
\text { Normal } \\
\text { Normal }\end{array}$ & $\begin{array}{l}\text { Normal } \\
\text { Normal } \\
\text { Normal } \\
\text { Normal } \\
\text { Normal }\end{array}$ & $\begin{array}{l}\text { Normal } \\
\text { Normal } \\
\text { Normal } \\
\text { Normal } \\
\text { Normal }\end{array}$ & $\begin{array}{l}- \\
\overline{\text { SMA }} \\
-\end{array}$ \\
\hline
\end{tabular}

$A N F=$ antinuclear factor; $M A=$ mitochondrial antibody; SMA $=$ smooth muscle antibody.

Table 5 Further tests in control workers

\begin{tabular}{llllll}
\hline Case & $\begin{array}{c}\text { BSP retention } \\
(\%)\end{array}$ & Scan & Barium meal & Endoscopy & Antibodies \\
\hline C1 & $8 \cdot 5$ & Patchy uptake & Normal & Oesophagitis & $\overline{\text { MA }}$ \\
C2 & $4 \cdot 4$ & Normal & Normal & Normal & MA \\
C3 & $13 \cdot 0$ & Normal & Normal & Normal & - \\
C4 & $9 \cdot 7$ & Normal & Normal & Normal & - \\
C5 & $19 \cdot 0$ & Patchy uptake & Duodenal scar & Two duodenal ulcers & \\
\hline
\end{tabular}

MA $=$ mitochondrial antibody

questioning suggested no alcohol excess or drug abuse. Glucose tolerance was normal but serum lipids were markedly increased. None of the other biopsies showed gross abnormalities but in five there was apparent capsular thickening and in nine, minor fibrotic changes were present in the portal tracts. In addition, careful study of the sinusoids suggested the likelihood of an increase in perisinusoidal reticulin. We have not attempted to quantify these changes. A separate study will report an attempt to quantitate sinusoidal reticulin using microdensitometric analysis (Cummings et al., 1976). Individually the biopsies revealed minor equivocal abnormalities which taken together raise the possibility of toxic liver damage as suggested by Marsteller et al., (1973).

\section{LIVER BIOPSIES IN CONTROLS}

Three of the biopsies were considered to be normal and in two there were definite changes. One man had portal cirrhosis of mild degree and weakly positive mitochondrial antibodies; his sister was said to have died of cirrhosis. The other abnormal biopsy specimen had an excess of iron in reticuloendothelial and parenchymal cells, with portal tract fibrosis insufficient to be classified as cirrhosis. The subject had an increase in serum iron with $96 \%$ saturation of the iron binding capacity and is considered to be a case of precirrhotic haemochromatosis.

\section{Discussion}

Vinyl chloride first came to prominence as an occupational hazard with the description of Raynaud's phenomenon, scleroderma-like skin changes and acro-osteolysis in autoclave workers (Cordier et al., 1966; Harris and Adams, 1967; Wilson et al., 1967). The disease appears to be selflimiting, most men suffering no permanent longterm effects. Suciu et al. (1967) commented that liver enlargement appeared to be part of the syndrome. Two reports from Bonn (Marsteller et al., 1973; Lange et al., 1974) provided further evidence of liver involvement in vinyl chloride disease. Autoclave workers suspected of having liver disease were studied following a screening procedure. Findings included thrombocytopenia, splenomegaly and portal hypertension. Capsular fibrosis was prominent at laparoscopy. Portal fibrosis and Kupffer cell hyper- 
plasia were considered to be more important histopathological findings than minor hepatic parenchymal cell changes. Thrombocytopenia could not be closely correlated with splenomegaly and portal hypertension, and was prominent in one man even after splenectomy. Findings at a large plant in Kentucky have been presented in two papers (Falk et al., 1974; Makk et al., 1974) following earlier reports of the occurrence there of hepatic angiosarcoma (Creech and Johnson, 1974). They summarised investigations of the livers of men in the plant, including the results of a screening programme of workers at risk. They were aware of 11 cases of liver disease including seven with angiosarcoma, two of whom were diagnosed as a result of screening. Portal fibrosis and atypical sinusoidal lining cells were found in all cases including those with a tumour. Estimation of $\gamma \mathrm{GT}$ was considered to be the most useful screening test. Lilis et al. (1975) reported the results of a screening programme in a plant at Niagara Falls, which suggested that a raised serum alkaline phosphatase was the most frequently abnormal test and showed the best correlation with clinical findings. Thomas et al. (1975) studied 18 livers and spleens from a group of 20 workers employed in vinyl chloride polymerisation, 15 of whom had angiosarcoma. Apart from the tumours there was a peculiar pattern of progressive portal fibrosis usually accompanied by splenomegaly, hypertrophy and hyperplasia of hepatocytes; hepatic and splenic mesenchymal cells were also seen. The similarity to chronic arsenical poisoning, another cause of hepatic angiosarcoma, and to idiopathic portal hypertension (Banti's syndrome) was noted. Smith et al. (1976a) described seven patients with portal hypertension secondary to non-cirrhotic portal fibrosis with high intrasplenic pressure and a slightly raised wedged hepatic vein pressure. A case of angiosarcoma has been reported from the same plant in South Wales (Smith et al., 1976b).

In the present series there was no significant difference in liver function tests between exposed workers and controls and no cases of angiosarcoma or florid vinyl chloride-induced liver disease were discovered. The minor histological changes in liver biopsy material could not be correlated with abnormalities in laboratory tests. It may be that similar minor changes are present in the men with normal tests. Other techniques, including greyscale ultrasonography, are under consideration as screening procedures in monitoring workers exposed to hepatotoxic chemicals (Williams et al., 1976).

We are grateful to Sister Hardman, Gastroenterology Unit and to Mrs M. Braun, Postgraduate Medical Centre, both of Victoria Hospital, Blackpool, and to
Mrs M. Owen, ICI Hillhouse, for administrative help. We have enjoyed discussions with Dr Robin Walker, Walton General Hospital, and Drs D. Duffield and P. Chivers, ICI Runcorn, on many aspects of the vinyl chloride problem. Professor $\mathrm{H}$. K. Weinbren, Postgraduate Medical School, Hammersmith Hospital, gave invaluable advice on the interpretation of the liver biopsy material. Dr Gordon Hamilton, Lancaster Royal Infirmary, kindly carried out the radioactive scans.

\section{References}

Axelsson, H., Ekman, B., and Knutson, D. (1965). Technicon Symposia. Automation in Analytical Chemistry, p. 603. Mediad Inc.: New York.

Barnes, A. W. (1976). Vinyl Chloride and the Production of P.V.C. Proceedings of the Royal Society of Medicine, 69, 277-281.

Block, J. B. (1974). Angiosarcoma of the liver following vinyl chloride exposure. Journal of the American Medical Association, 229, 53-54.

Cordier, J. M., Fievez, C., Lefevre, M. J., and Sevrin, A. (1966). Acro-osteolyse et lesions cutanées associées chez deux ouvriers affectés au nettoyage d'autoclaves. Cahiers de Mêdecine du Travail, 4, 1-39.

Creech, J. L. Jr., and Johnson, M. N. (1974). Angiosarcoma of liver in the manufacture of polyvinyl chloride. Journal of Occupational Medicine, 16, 150-151.

Cummings, R., Weinbren, K., Lee, F. I., and Walker, R. J. (1976). A microdensitometric analysis of sinusoidal reticulin in workers exposed to vinyl chloride. (In preparation).

Falk, H., Creech, J. L. Jr., Clark, W. H., Johnson, M. N., and Key, M. M. (1974). Hepatic disease among workers at a vinyl chloride polymerization plant. Journal of the American Medical Association, 230, 59-63.

Harris, D. K., and Adams, W. G. F. (1967). Acro-osteolysis occurring in men engaged in the polymerization of vinyl chloride. British Medical Journal, 3, 712-714.

Health and Safety Executive. Vinyl Chloride Code of Practice for Health Precautions. HMSO: London.

Kessler, C., Rush, R. L., Leon, L., Delea, A., and Cupiola, R. (1971). In Advances in Automated Analysis, p. 67. Phurman Associates: Miami, Florida.

Lange, C. E., Juhe, S., Stein, G., and Veltman, G. (1974). Vinyl chloride disease-an occupational system-sclerosis? Internationale Archiv für Arbeitsmedizin, 32, 1-32.

Lee, F. I., and Harry, D. S. (1974). Angiosarcoma of the liver in a vinyl chloride worker. Lancet, 1, 1316-1318.

Lilis, R., Anderson, H., Nicholson, W. J., Daum, S., Fischbein, A. S., and Selikoff, I. (1975). Prevalence of disease among vinyl chloride and polyvinyl chloride workers. Annals of New York Academy of Sciences, 246, 2241.

Makk, L., Creech, J. L. Jr., Whelan, J. G., and Johnson, M. N. (1974). Liver damage and angiosarcoma in vinyl chloride workers. Journal of the American Medical Association, 230, 64-68.

Marsteller, H. J., Lelbach, W. K., Müller, R., Juhe, S., Lange, C. E., Rohner, H. G., and Veltman, G. (1973). Chronic toxic liver damage in workers on PVC production. Deutsche Medizinische Wochenschrift, 98, 2311-2314.

Smith, P. M., Crossley, I. R., and Williams, D. M. J. (1976a). Portal hypertension in vinyl-chloride production workers. Lancet, 2, 602-604.

Smith, P. M., Williams, D. M. J., and Evans, D. M. D. 
(1976b). Hepatic angiosarcoma in a vinyl chloride worker. Bulletin of the New York Academy of Medicine, 52, 447452.

Suciu, I., Drejman, I., and Valaskai, M. (1967). Études des maladies dues au chlorure vinyle. Medicin Lavoro, 58, 261271.

Thomas, L. B., Popper, H., Berk, P. D., Selikoff, I., and Falk, H. (1975). Vinyl-chloride induced liver disease. New England Journal of Medicine, 292, 17-22.
Williams, D. M. J., Smith, P. M., Taylor, K. J. W., Crossley, I. R., and Duck, B. W. (1976). Monitoring liver disorders in vinyl chloride monomer workers using greyscale ultrasonography. British Journal of Industrial Medicine, 33, 152157.

Wilson, R. H., McCormick, W. E., Tatum, C. F., and Creech, J. L. Jr. (1967). Occupational acro-osteolysis. Journal of the American Medical Association, 201, 83-87. 